\title{
計算科学上実験科学の組み合わせにより明らかになった 多乵排出卜ランスポーターAcrBの分子メカニズム
}

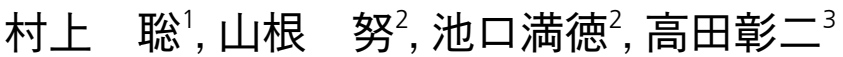

'東京工業大学大学院生命理工学研究科

${ }^{2}$ 横浜市立大学大学院生命医科学研究科

京都大学大学院理学研究科

Since nearly all protein molecules acting in cell are working dynamically, dynamic aspects of them are indispensable to understand each biological system. Recent advances in synchrotron-based crystallography and computational chemistry have allowed to provide dynamic aspect in high-resolution crystal structures. Here we review our structural and functional studies on multi-drug efflux transporter, AcrB. Crystal structure analysis and molecular dynamics (MD) simulation are complemental techniques. And synergy between them makes static crystal structures more animate. Proton is another nuisance in protein crystallography, since it is almost invisible technically. MD simulation can allow systematic examination of protonation states in titratable residues.

Membrane transport / Multi-drug resistance / Molecular dynamics simulation / Membrane Protein / Protein crystallography

1.はじめに:結晶解析と分子動力学計算

蛋白質や核酸などの原子レベルの立体構造を基にそ の働きを研究する構造生物学は，最近の分子生物学的 手法，シンクロトロン放射光や計算機技術の発達によ り，近年旺然たる進展を久せ，多くの興味深い生体反 応をつかさぞる蛋白質，蛋白質複合体の原子レベルで の立体構造を明らかにし，構造に基づくそれら反応の 本質的な理解に大きく貢献してきた。 ここ十年のノー ベル化学賞を見ると 2012 年 $(G$ 蛋白質共役受容体の 研究), 2009 年 (リボソームの構造と機能の研究), 2006 年（真核生物に和ける転写の研究），2003 年（イ オンチャネルの構造打よび機能の研究）と数年に一度 の頻度で生体高分子の構造に基づく機能の本質的解明 にノーベル化学賞が与えられている。ここでとりわけ 着目したいのがノーベル化学賞であり, 医学生理学賞 でないといら点である。受容体，とりわけ $\mathrm{G}$ 蛋白質 や，蛋白質合成，イオンチャネルに関する研究は， ノーベル化学賞以前に，それ炅れノーベル医学生理学 賞を受けている ${ }^{11}$ 。つまり改めてノーベル化学賞が与 えられたのは，それらの生命現象の理解が化学の領域 に達したといらことを意味している．蛋白質分子中で
起こる種々の反応や相互作用をつかさどる官能基の立 体配置を原子レベルで観察し，現象を化学や物理の言 葉での理解へと導くX線結晶構造解析は, 構造生物 学分野における中心的役割を演じてきたことは異論の 余地がない，X線結晶構造解析の結果得られる構造は 結晶中に含まれる数多ある分子の平均構造であり, 精 度が極めて高い特長がある，その一方で，そ故ある 定位の構造を反映する．生体内でダイナミックに摇ら ぎ機能する蛋白質分子の動的な様相は，これもまた平 均化され，静的な情報を与兄るのみとなる。このこと はX線結晶構造解析の欠点というべきかもしれない. 反応中間体を多数, 詳細に結晶構造解析することで, 至極尤もらしい機構図を表すスムースな動画を与えた 目覚ましい解析例もあるが2)，これも所謂パラパラ漫 画であり各々は静止した図画である。その欠点を補 い，構造に動的な知見を与光ると考学られるのが，分 子動力学（MD）シミュレーション計算である.

かつて著者（村上）の恩師は，「X 線結晶構造解析 はこれまで成されてきた多くの生化学実験なぞの合理 的解釈の答え合わせとして使われる側面を持つため, それは当該学問分野に拈けるゴールであると思われる 節がある。しかし，それは誤りでむしろスタートであ

Molecular Mechanism of Multi-drug Efflux Transporter, AcrB Revealed by the Synergy between Molecular Dynamics Simulation and Crystallography

Satoshi MURAKAMI ${ }^{1}$, Tsutomu YAMANE ${ }^{2}$, Mitsunori IKEGUCHI ${ }^{2}$ and Shoji TAKADA ${ }^{3}$

${ }^{1}$ Graduate School of Bioscience \& Biotechnology, Tokyo Institute of Technology

${ }^{2}$ Graduate School of Medical Life Science, Yokohama City University

${ }^{3}$ Graduate School of Science, Kyoto University 
る．結晶構造を基に研究を展開することで，よりリア リティーのある研究が開始できるのである.」と宣っ た．MD 計算は高精度の分子構造モデルがないと開始 できない。また結晶構造は MD 計算なくしては動的 な様相を得ることは難しい。そういった意味におい て，MD 計算と結晶構造解析は極めて相補的な技法で あるといえる。これまで実験科学を旨とする結晶学者 は, シミュレーションは比較的小さな分子による速い 反応の場合の夕に適用しらるもので，巨大な蛋白質に 含まれる何万個もの原子を，水中や脂質膜中の然るべ き環境下で，且つ然るべき反応時間計算することは， 技術的な限界を超えていると考えていた。 しかし，昨 今の計算機や計算技法の発達によりそれが可能とな り, 既に多くの興味深い研究を支えている. 而して 2013 年ノーベル化学賞は複雑な化学反応に関するマ ルチスケールモデルの開発に与えられた ${ }^{11}$. 構造生物 学の 1 つの手法として, MD 計算が積極的に使われる 時代が来たことを意味すると考えている.

\section{2. 動機:Post-structure の3つの新たな動機}

著者らは細菌の多剤耐性化の主因の1つである多剤 排出トランスポーターの構造と機能に興味を持って 共同研究を進めてきた。 世界初となった多剂排出卜 ランスポーターの結晶構造解析は大腸菌 AcrB につい て 2002 年に行われた ${ }^{3)}$.さらに2006年には基質複合 体など分子機構解明に迫る非対称的な構造が得られ た ${ }^{4)}$. AcrB はホモ三量体で機能するが，各々のプロト マーは，構造が異なり，それに応じて薬剤排出機構に おける機能状態が異なる。それぞれ，基質を取り込む 状態 (Access), 結合する状態 (Binding), 排出する状 態 (Extrusion) にあると解釈できた。 それを基にATP 合成酵素の回転触媒説 ${ }^{5)}$ の類推によって動的な解釈が なされ機能的回転メカ二ズムを提唱した ${ }^{4)}$. しかし， 先述のとおり結晶構造は静的な構造であり, 動的な解 釈については想像の域を脱することはない. そこで $\mathrm{MD}$ 計算による検証が必要となる3つの新たな動機が 生まれた. (1)この構造非対称性は, 類推の元となった ATP 合成酵素に扔いては， ヌクレオチド結合状態の違 いであるとされたが，AcrBに拈ける非対称性でも同 様に，基質の結合が要因になっているのではないかと 考えた.さらに 2002 年に解かれた構造では結晶学的 な対称性によりこの三量体が対称的な構造を取ってい たが，それが単なる結晶学的なアーチファクトなのか 生理的に意義のあるものか? 新たな動機が生まれた.

さらに, 結晶学における上記の欠点の他に挙げられ
ることは，プロトンを観察することが困難（或いは不 可能）である点である. AcrB の機能的回転は細胞膜 を介したプロトン濃度勾配をエネルギー源としてい る. 結晶構造解析では，3種のプロトマー各々が持つ 膜貫通へリックスの束の中央部分に，2つのアスパラ ギン残基と，それらと塩橋をつくる1つのリジン残基 があり，その部分がプロトン化 / 脱プロトン化するこ とで膜貫通部分に構造変化を来し，それが遠隔構造変 化伝搬により分子全体の動きとなると考えられてい る.そこで(2) 3 種のプロトマーのうち, どのプロト マーの有するどのアスパラギン酸がプロトン化される のか？に興味が持たれる．プロトン化状態を違えた構 造を観察すれば，3種のうちどの機能状態となるかを 明らかにする新たな動機が生まれた。

さらに，この種の薬剤排出トランスポーターは細胞 膜上で働く掃除機に例えられて扣り（Vacuum cleaner theory $)^{6}$, 細胞膜の外葉付近にある脂溶性に富んだ基 質を言わば分子中に「吸い込む」。このような動的な 様相はやはり結晶構造では得ることは難しく，(3)基質 が想定される基質取り込み口から，基質結合部位へと 透過経路中を動いて行く様を観察したいといら動機が 生まれた。このように結晶構造の解析後, 機能を考察 する際に新たな3つの動機が生まれた。

\section{3. 結果と考察:MD 計算だからできたこと}

(1)については2006 年に用いた非対称性を観察する ことが可能な晶系で，基質を加えずに結晶構造を解け ば答えが得られると考えられるが，そこで問題が生じ た。それは AcrB が界面活性剂を基質とする事実であ る. 抗生物質や抗がん剂などの基質を加えずとも，精 製のために界面活性剂を加えるため, 厳密な意味での アポ体は得ることが難しい，勿論界面活性剂を用いず には結晶化は扔ろか精製も不可能である。そこで分子 動力学計算に依ることにした. 万法としては，2006年 に明らかにした AcrB ミノサイクリン複合体の結晶構 造を出発モデルとし, 分子動力学シミュレーション計 算を開始する。十分な時間を経て安定を観た後，ある タイミングで座標トラジェクトリーから，結合基質の 座標のみを消し去り，計算を続行する，その後再び十 分な時間シミュレーション計算を行った後，得られた 三量体が各々 3 種のらちどの構造状態にあるか? を構 造的特徵から分類しその出現頻度を調べた。 このよう な計算を何本も走らせ，結論として基質存在下，非存 在下での構造の安定化や構造変化を統計的に解析した （図 1)。ここでは，340 kDa もの巨大な蛋白質の MD 


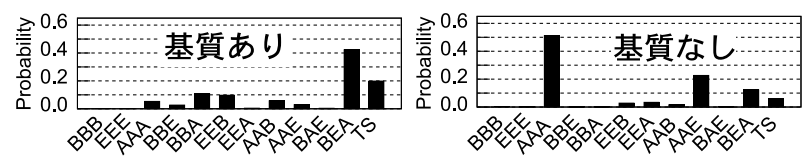

図 1

シミュレーション計算後の三量体構造に含まれる各々のプロト マーの分属. 基質あり（左）では計算後も初期モデルである非対 称構造（BEA:本文参照）が多く保たれるのに対し，基質なし（右） では対称的な構造（AAA:3 分子とも基質取り込み型）が最も多く 観察された. TS:遷移状態.

計算を多くの異なる条件で行う必要があり，計算を軽 減させる手法である粗視化モデルによる MD 計算を 行った。この手法は，各アミノ酸を 1 つの球として表 現することで自由度を減らし計算を軽減せしめる手法 であり，巨大分子の大きな構造変化などを捉える目的 の MD 計算にしばしば用いられてきだ7. その結果, 基質存在下で，非対称性構造である結晶構造が安定 で，初期構造を保つ（図 1右-BEA）ような条件下で, 基質非存在下では，この構造は不安定化し，三量体は 次第に対称的な構造をとる (図1左-AAA)。さらにこの 対称的な構造は2002年の結晶学的対象を持つ構造に近 いことが分かった ${ }^{8}$. ATP 合成酵素と同様，基質が非 刘称性を生む要因であり，基質がないときには，対称 的な基質待ちの休止状態となることが示唆された ${ }^{8)}$.

(2)について，プロトン化状態を変化させたければ, 例光ば酸性或いは塩基性の緩衝液に結晶を浸潤させ， 構造を解くことによりプロトン化/脱プロトン化状態 の構造の違いを観察することができるが，我々の研究 目的に対してそれは全く意味をなさない，非対称的な 三量体は各々プロトン化状態が異なっている。そのた め, 結晶をある水素イオン濃度の緩衝液に浸潤させれ ば，三量体に含まれる荷電性アミノ酸の状態が遍く変 化してしまらだろう。我々はそらではなく，ある特定 のプロトマーに含まれる2つのアスパラギン酸側鎖の 片方ずつのプロトン化状態を変化させたいのである. それには，シミュレーション計算以外には方法はない と思われた，方法としては，2006年に明らかにした 結晶構造を出発モデルとし，三量体にそれぞれ含まれ る 2 つのアスパラギン酸と， 1 つのリジン残基の荷電 状態を幾種類か仮定し，それで分子動力学シミュレー ションを開始する。十分な時間シミュレーション計算 を行った後，座標トラジェクトリーの構造的特徵を観 察し構造の安定性を調べた ${ }^{9}$ 。荷電状態の仮定が間 違っているならば構造は安定せず変化する。このよう な計算を証明に必要な場合の数だけ多数実行した。そ の結果，三量体のらち，「基質排出型」と呼ばれる構 造機能状態の持つ片方のアスパラギン酸 D408 のみが

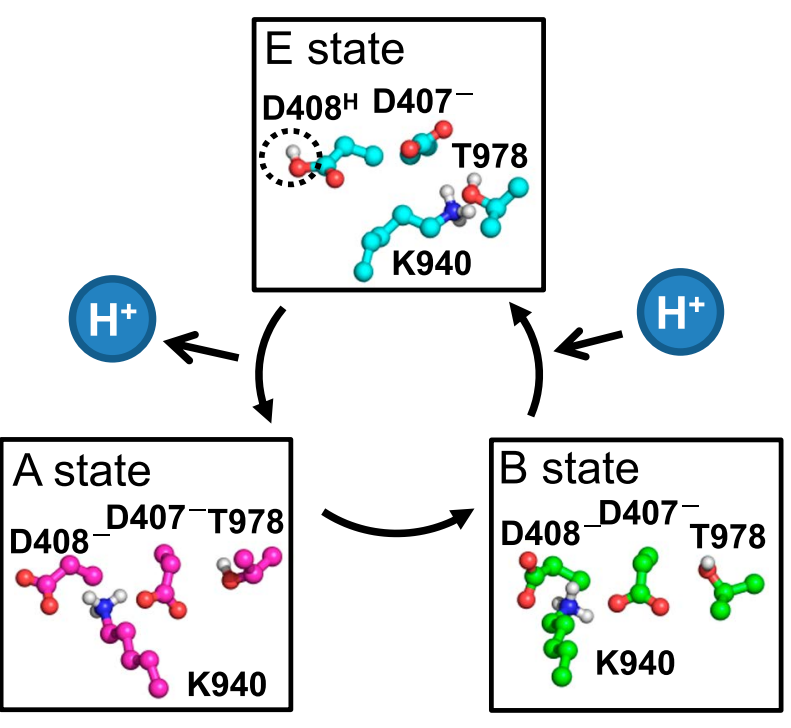

図 2

AcrB のプロトン化サイクル. 非対称的な構造に含まれる A， B , E の各プロトマーの膜貫通部分に存在するプロトン透過に関わる重 要な荷電性アミノ酸におけるプロトン化の様相.

プロトン化されていることが分かった（図 2) ${ }^{9}$. ささら に，一連の計算では膜貫通部分の荷電性アミノ酸のプ ロトン化状態を変化させることで誘起される構造変化 が，分子中の離れた別のドメインの構造変化として遠 隔構造変化伝搬するところも観察できた ${ }^{9)}$. ここでは, 荷電性アミノ酸のプロトン化状態の違いなどアミノ酸 側鎖の原子レベルでの詳細な議論が必要であり，粗視 化モデルではなく全原子モデルを用いた MD 計算を 行う必要があった。蛋白質, 細胞膜, 溶媒も含め約 47 万個もの原子について，合計でマイクロ秒スケー ルまで MD 計算を行うのには長大な時間を要した.

(3)こそは，分子動力学シミュレーション計算以外で それを調べる方法はないと考兄られる. 方法としては, 2006 年に明らかにした結晶構造を基に，排出される べき基質が存在するであろら基質取り込み口近傍に薬 剤分子モデルを置きシミュレーション計算を行い，座 標トラジェクトリ一の薬剂分子の動きの軌跡に着目し た. 複数の取り込み口の可能性を考光て複数の計算を 行い，それらの統計処理を施しどのような経路で薬剤 分子がAcrB分子中に取り込ま机排出されてゆくのかを 見た ${ }^{10)}$ 。その結果，AcrB の薬剂取り込及口（vestibule） と考兄られている部位から予想通り基質は取り込まれ ることをシミュレーション計算でも観察することがで きたが，さらに基質の大きさや疎水性の違いにより，考 えていた基質透過経路以外にも幾らか他の経路を経る 可能性が見いだされた (図3 $)^{10)}$ 。これらの経路はいず 孔もAcrB 分子内に開いた疎水性のトンネルで, 細胞膜 外葉に核淁接するように存在する基質取り込久口を形 


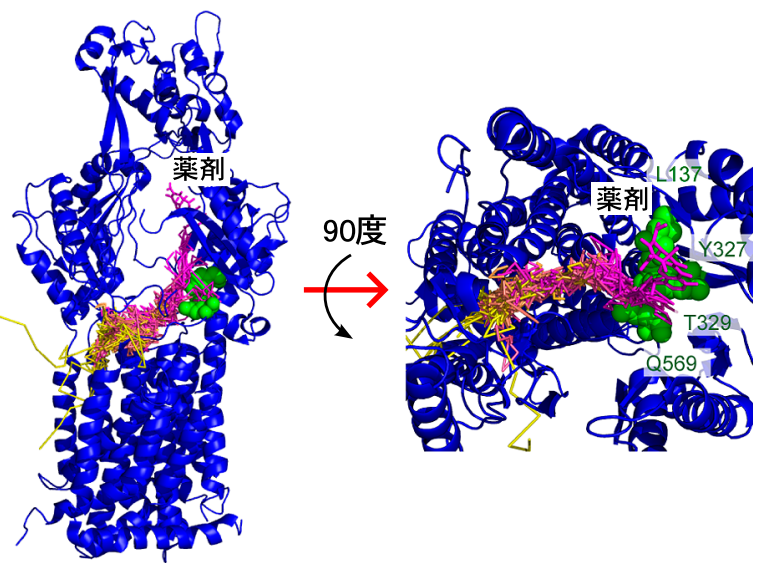

図 3

計算により求められた基質輸送の軌跡. 細胞膜に対して平行な方 向（左）からと垂直な方向（右）からのリボン図. 基質分子の重 心位置の軌跡をトラジェクトリーの時間により色分けした（初期： 黄色 終期:マゼンタ)。 また, 基質結合部位に結合したミノサイ クリン分子（マゼンタ）と基質透過経路を成す幾らかのアミノ酸 残基（緑）を描いた.

作っており，疎水性に富む基質がそこを経てゆくと考 えられた.さらにその経路の信憑性を検証するために, 示された新たな基質透過経路を成すアミノ酸残基に対 して部位特異的変異導入を行い, 得られた变異体の基 質排出活性を測定した。その結果，計算科学により新 たに見いだされた基質透過経路もまた基質輸送に重要 な役割を担うということが実験的にも示された ${ }^{10)}$ 。こ れについては,各アミノ酸を主鎖と側鎖の 2 つの球で 近似する粗視化モデルによる MD 計算を行った。

4. まとめと考察:相乗効果サイクル

細胞内では蛋白質はダイナミックに摇らぎながら機 能しているのだから，動的な解釈は必須で，静止画で ある結晶構造にライブなイメージを与える分子動力学 シミュレーション計算は構造生物学分野において大変 重要な意義を持つ，座標データが無いと計算ははじめ ることができないので, 結晶解析, MD 計算という順 序になるが，計算の後，結果を検証するために，再び 実験科学に下駄が戻されることもある．生化学実験や 変異体の構造解析などが行われ, 座標卜ラジェクト リーに観られる構造の確かさが検証される。ささらにそ の検証の結果を受けて，次なる実験或いは計算の動機 が生まれるかもしれないし，計算アルゴリズムの改良 などにも生かされるか子しれない，結晶解析や生化学 測定を行ら実験屋と, MD 計算を行ら計算屋の研究は 極めて相補的であり, 且つそのシナジー（相乗効果） により面白い構造研究へと繋がっていく，米国では
$\mathrm{MD}$ 専用計算機が開発され，桁外れに大規模な計算が 行われているが，我が国でもソフト，ハード両面から の当該分野の発展扣よび国家的な支援が望まれる.

文 献

1) http://www.nobelprize.org

2) Toyoshima, C. (2008) Arch. Biochem. Biophys. 476, 3-11. DOI: 10.1016/j.abb.2008.04.017.

3) Murakami, S. et al. (2002) Nature 419, 587-593. DOI: 10.1038/ nature01050.

4) Murakami, S. et al. (2006) Nature 443, 173-179. DOI: 10.1038/ nature 05076.

5) Boyer, P. D. (1993) Biochim. Biophys. Acta 1140, 215-250. DOI: 10.1016/0005-2728(93) 90063-L.

6) Bolhuis, H. et al. (1997) FEMS Microbiol. Rev. 21, 55-84. DOI: 10.1111/j.1574-6976.1997.tb00345.x.

7) Kenzaki, H. et al. (2011) J. Chem. Theor. Comp. 7, 1979-1989. DOI: $10.1021 / \mathrm{ct} 2001045$.

8) Yao, X. Q. et al. (2010) Nat. Commun. 1, 117. DOI: 10.1038/ ncomms1116.

9) Yamane, T. et al. (2013) Biochemistry 52, 7648-7658. DOI: $10.1021 / \mathrm{bi} 400119 \mathrm{v}$.

10) Yao, X. Q. et al. (2013) J. Am. Chem. Soc. 135, 7474-7485. DOI: $10.1021 / \mathrm{ja} 310548 \mathrm{~h}$.

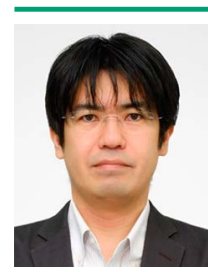

村上 聡（むらかみ さとし）

東京工業大学大学院生命理工学研究科教授

1997 年大阪大学大学院博士後期課程修了, 大阪 大学産業科学研究所助手, 助教授を経て 2008 年 より現職.

研究内容:膜蛋白質，とりわけ膜輸送体の構造生 物学

村上 聡連絡先: $=226-8501$ 神奈川県横浜市緑区長津田町 4259

E-mail: murakami@bio.titech.ac.jp

山根 努（やまね つとむ）

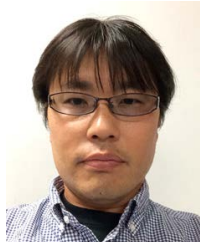

横浜市立大学大学院生命医科学研究科特任助教 1999 年東京工業大学大学院博士後期課程修了, 横浜市立大学大学院博士研究員を経て 2007 年よ り現職.

研究内容:蛋白質の分子シミュレーション

山根 努

連絡先: T230-0045 神奈川県横浜市鶴見区末広町 1-7-29

E-mail: tyamane@tsurumi.yokohama-cu.ac.jp

池口満徳（いけぐち みつのり）

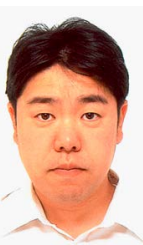

横浜市立大学大学院生命医科学研究科准教授 1994 年東京大学大学院農学系研究科博士課程修 了, 東京大学助手, 横浜市立大学大学院助教授を 経て 2007 年より現職.

研究内容: 生体分子の分子シミュレーション

連絡先: $7230-0045$ 神奈川県横浜市鶴見区末広町

池口満徳

1-7-29

E-mail: ike@tsurumi.yokohama-cu.ac.jp

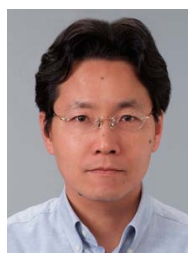

高田彰二（たかだ しょうじ）

京都大学大学院理学研究科教授

1990 年京都大学大学院修士課程修了, 神戸大学講

師, 助教授, 京大准教授を経て 2013 年より現職. 研究内容: 理論生物物理学, 特に生体分子複合系 の分子シミュレーション

連絡先: $=606-8502$ 京都市左京区北白川追分町

高田彰二 